\title{
Mixed-ligand complexes of ruthenium(II) incorporating a diazo ligand: Synthesis, characterization and DNA binding
}

\author{
MEGHA S DESHPANDE and AVINASH S KUMBHAR* \\ Department of Chemistry, University of Pune, Pune 411 007, India \\ e-mail: askum@chem.unipune.ernet.in
}

\begin{abstract}
Mixed-ligand complexes of the type $\left[\mathrm{Ru}(\mathrm{N}-\mathrm{N})_{2}(\mathrm{dzdf})\right] \mathrm{Cl}_{2}$, where $\mathrm{N}-\mathrm{N}$ is $2,2^{\prime}$-bipyridine (bpy), 1,10-phenanthroline (phen) and 9-diazo-4,5-diazafluorene (dzdf), have been synthesized and characterized by elemental analysis, UV-Vis, IR and NMR spectroscopy. Binding of these complexes with calf thymus DNA (CT-DNA) has been investigated by absorption spectroscopy, steady-state emission spectroscopy and viscosity measurements. The experimental results indicate that the size and shape of the intercalating ligands have marked effect on the binding affinity of the complexes to CT-DNA. The complex $\left[\mathrm{Ru}(\mathrm{phen})_{2}(\mathrm{dzdf})\right] \mathrm{Cl}_{2}$ binds with CT-DNA through an intercalative binding mode, while the complex $\left[\mathrm{Ru}(\mathrm{bpy})_{2}(\mathrm{dzdf})\right] \mathrm{Cl}_{2}$ binds electrostatically.
\end{abstract}

Keywords. Ruthenium(II) polypyridyl complexes; 9-diazo-4,5-diazafluorene ligand; DNA binding.

\section{Introduction}

The interaction of transition metal complexes with nucleic acids is a major area of research due to the utility of these complexes in the design and development of synthetic restriction enzymes, chemotherapeutic agents, footprinting agents, spectroscopic probes, site-specific cleavers and molecular photoswitches. ${ }^{1}$ Ruthenium polypyridyl complexes have been extensively studied in this context as their luminescence and photochemical reactivity make them exceptionally versatile as probes of DNA structures. ${ }^{2-8}$ These complexes bind to DNA by non-covalent interactions such as electrostatic binding, groove binding, intercalative binding and partial intercalative binding. ${ }^{9}$ Barton et al have pioneered the application of chiral transition-metal polypyridyl complexes to probe local variations in double-helical DNA structures and their role in gene expression, ${ }^{9-13}$ and have recently reported the mismatch recognition agent $\left[\mathrm{Rh}(\mathrm{bpy})_{2}\right.$ $(\text { chrysi) }]^{3+}$ (chrysi $=5,6$-chrysenequinone diimine) that binds mismatch sites in DNA specifically and upon photoactivation cleaves the DNA backbone neighbouring the mismatch site. ${ }^{14}$ Andree Kirsch-De Mesmaeker and coworkers ${ }^{15}$ have developed bifunctional $\mathrm{Ru}(\mathrm{II})$ complex $\left[\mathrm{Ru}(\mathrm{TAP})_{2} \mathrm{POQ}-\mathrm{Nmet}\right]^{2+}$ composed of a $\left[\operatorname{Ru}(\mathrm{TAP})_{2}(\text { phen })\right]^{2+}$ unit linked to an $\mathrm{N}$-methyl-aminoquinoline moiety by a seven-atom

Dedicated to the memory of the late Professor Bhaskar G Maiya *For correspondence chain $\quad(\mathrm{TAP}=1,4,5,8$-tetraazaphenanthrene), the emission of which is dependent on the guanine content of the polynucleotide, thus developing a novel DNA sensor for guanine content. ${ }^{15}$ They have also synthesized complexes with extended aromatic ligands such as $\left[\mathrm{Ru}(\mathrm{phen})_{2}(\mathrm{dppz})\right]^{2+16}(\mathrm{dppz}=$ dipyrido [3,2-a: $\left.2^{\prime}, 3^{\prime}-\mathrm{c}\right]$ phenazine), $\left[\mathrm{Ru}(\mathrm{bpy})_{2} \text { (hat) }\right]^{2+17}$ (hat $=$ 1,4,5,8,9,12-hexaazatriphenylene $), \quad\left[\mathrm{Ru}(\text { phen })_{2}\right.$ (phehat) ${ }^{2+18}$ (phehat = 1,10-phenanthrolino[5,5-b]1, $4,5,8,9,12$-hexaazatripheny-lene) and $\left[\mathrm{Ru}(\mathrm{phen})_{2}\right.$ $(\mathrm{dpq})]^{2+19}\left(\mathrm{dpq}=\right.$ dipyrido[3,2-d: $2^{\prime}, 3^{\prime}-f$ ] quinoxaline $)$ which facilitate strong non-covalent binding interactions especially through complete or partial intercalation of one of the ligands. Complexes such as $\left[\operatorname{Ru}(\text { phen })_{2}(\mathrm{dppz})\right]^{2+}$ or $\left[\mathrm{Ru}(\text { phen })_{2}(\text { phehat })\right]^{2+}$ are not luminescent in aqueous solution, but their emission is switched on when they intercalate a portion of their extended aromatic ligand into the stacking of the DNA bases. ${ }^{16 a, 18,20}$ It has also been shown that the complexes of the type $\left[\mathrm{Ru}(\mathrm{TAP})_{2}(\mathrm{dppz})\right]^{2+}$ undergo photo-induced proton-coupled electron transfer with guanosine-5'-monophosphate. ${ }^{21}$ Liang Nian Ji et al have shown simple modifications on the ancillary ligands create interesting differences in space configurations and electron-density distribution of $\mathrm{Ru}(\mathrm{II})$ polypyridyl complexes which result in different DNA binding behaviours. ${ }^{22}$ In another report, a series of $\mathrm{Ru}(\mathrm{II})$ polypyridyl complexes containing phenylhydrazones derived from 4,5-diazafluorene-9-one were synthesized which bind to CT DNA through variety of modes. ${ }^{22 \mathrm{e}}$ Maiya et $a l^{23}$ reported "molecu- 
lar light switch" and "electro-photo switch" effects for complexes containing either a quinone-fused (qdppz $=$ naphtha $\quad[2,3-$ a $]$ dipyrido[3,2-h: $\left.\quad 2^{\prime}, 3^{\prime}-f\right]$ phenazine-5,18-dione) or a dicyano aromatic subunit (6,7-dicyanodipyridoquinoxaline) dppz based ligand and recently studied the redox chemistry of $\mathrm{Ru}(\mathrm{II})$ complexes of 6,7-dicyanodipyridoquinoxaline by pulse radiolysis techniques. ${ }^{23 \mathrm{~d}}$ They have also extended studies with a new modified phenanthroline ligand $\quad(\mathrm{ptzo}=1,10$-phenanthrolino[5,6-e $] 1,2,4-$ triazine-3-one) showing moderate affinity for binding with CT DNA. ${ }^{23 e}$ Many useful applications of all the above complexes require that the complexes bind to DNA by an intercalative mode with a planar aromatic ligand that has been modified extensively, while the role of ancillary ligand has not been investigated in detail. Zaleski et $a l^{24}$ have recently reported that 9diazo-4,5-diazafluorene a nitrogen chelate-containing an exocyclic diazo group complexes with copper and effectively photocleaves DNA under anaerobic conditions using visible light. However, the interactions of other transition metal complexes containing the dzdf ligand and DNA have not been investigated. In this paper, we have synthesized and characterized $\mathrm{Ru}$ (II) polypyridyl complexes of the type $\left[\mathrm{Ru}(\mathrm{N}-\mathrm{N})_{2} \mathrm{dzdf}\right] \mathrm{Cl}_{2}$ where $\mathrm{N}-\mathrm{N}$ is bpy, phen and dzdf is 9-diazo-4,5-diazafluorene ancillary ligand. The DNA binding of these complexes has been examined by absorption titration, luminescence quenching of ethidium bromide (EB) bound to DNA and viscosity measurements.

\section{Experimental}

\subsection{Materials}

All reagents and solvents were purchased commercially and were used as received. $\mathrm{RuCl}_{3} . n \mathrm{H}_{2} \mathrm{O}$ was obtained from SD Fine Chemicals (India). Calf thymus DNA was purchased from SRL (India). Double-distilled water was used to prepare phosphate buffer. DNA concentration per nucleotide was determined by absorption spectroscopy using the molar absorption coefficient $\left(6600 \mathrm{M}^{-1} \mathrm{~cm}^{-1}\right)$ at $260 \mathrm{~nm}$. Solutions of calf thymus DNA in phosphate buffer gave a ratio of absorbance at 260 and $280 \mathrm{~nm}$ of $1.8-1.9: 1$, indicating that the DNA was sufficiently free of protein. ${ }^{25}$

4,5-Diazafluoren-9-one (dafone), ${ }^{26}$ 4,5-diazafluorenone 9-hydrazone (dzdfh) ${ }^{27}$ and 9-diazo 4,5-diazafluorene $(\mathrm{dzdf})^{27}$ were synthesized by the reported procedures modified as shown below. $\left[\mathrm{Ru}(\mathrm{bpy})_{2}\right.$ $\left.\mathrm{Cl}_{2}\right] \cdot 2 \mathrm{H}_{2} \mathrm{O}$ and $\left[\mathrm{Ru}(\text { phen })_{2} \mathrm{Cl}_{2}\right] \cdot 2 \mathrm{H}_{2} \mathrm{O}$ were synthesized by the literature procedures. ${ }^{28}$ Structures of the various polypyridyl ligands and the $\mathrm{Ru}(\mathrm{II})$ complexes used in the present study are given in figure 1 .

\subsection{Synthesis of ligands}

2.2a 4,5-Diazafluoren-9-one (dafone): 1,10-Phenanthroline $(9 \mathrm{~g}, 0.05 \mathrm{M})$ and $\mathrm{KOH}(5 \mathrm{~g}, 0.09 \mathrm{M})$ were added to $850 \mathrm{ml}$ of water and brought to reflux. $\mathrm{KMnO}_{4}(25 \cdot 30 \mathrm{~g}, 0 \cdot 16 \mathrm{M})$ in $400 \mathrm{ml}$ water was added dropwise to the refluxing mixture. After addition the solution was refluxed for $1 \mathrm{~h}$ and filtered to remove $\mathrm{MnO}_{2}$; when the solution was cooled, crude 4,5-diazafluoren-9-one precipitated as yellow needles. Yield: $40 \%$, m.p. $=212^{\circ} \mathrm{C}$.

2.2b 4,5-Diazafluorenone-9-hydrazone (dzdfh): 4,5-Diazafluoren-9-one (5 g, 0.027 mmol) and excess hydrazine hydrate in the presence of glacial acetic acid was refluxed in $100 \mathrm{ml}$ methanol for $4 \mathrm{~h}$ resulting in the formation of 4,5-diazafluorenone-9-hydrazone. Yield $=70 \%$, m.p. $=198-205^{\circ} \mathrm{C}$.

2.2c 9-Diazo 4,5-diazafluorene (dzdf): 4,5-Diazafluorenone-9-hydrazone $(1.0 \mathrm{~g}, 5.1 \mathrm{mmol})$ was oxidized using a basic solution (8 drops of saturated $\mathrm{KOH}$ in water) of yellow $\mathrm{HgO}(1.2 \mathrm{~g}, 5.5 \mathrm{mmol})$ in benzene $(100 \mathrm{ml})$. The solution was stirred overnight at room temperature and then filtered through glass wool or filter paper to remove the insoluble product of $\mathrm{Hg}$ waste. The resulting orange solution was concentrated to a solid and then recrystallised from a mixture of dichloromethane and pentane at $-20^{\circ} \mathrm{C}$. Yield: $60 \%$, m.p. $=160^{\circ} \mathrm{C}$.

\subsection{Synthesis of ruthenium(II) polypyridyl complexes}

2.3a $\left[R u(b p y)_{2}(d z d f)\right] C l_{2}:$ A mixture containing $\left[\mathrm{Ru}(\mathrm{bpy})_{2} \mathrm{Cl}_{2}\right] \quad(0.100 \mathrm{~g}, \quad 0.19 \mathrm{mmol}) \quad$ and $\mathrm{dzdf}$ $(0.037 \mathrm{~g}, 0.19 \mathrm{mmol})$ was refluxed in methanol/ water $(1: 1)$ for $5 \mathrm{~h}$ to give a dark red solution. The solution was cooled to room temperature. After evaporation of the solvent, the solid was collected, washed with small amounts of methanol and diethyl ether, and dried under suction. The product was purified by column chromatography on alumina using acetone and methanol as eluent. Yield $=55 \%$. 


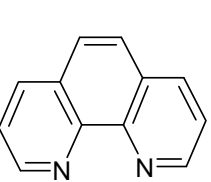

1,10-phenanthroline

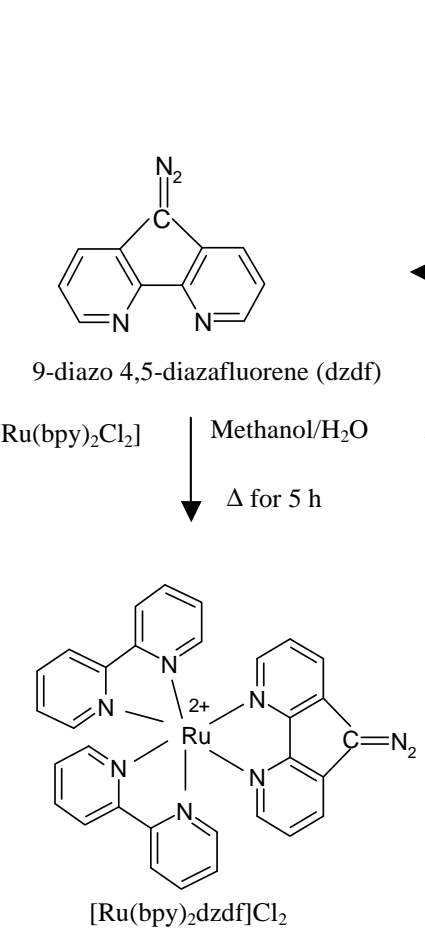

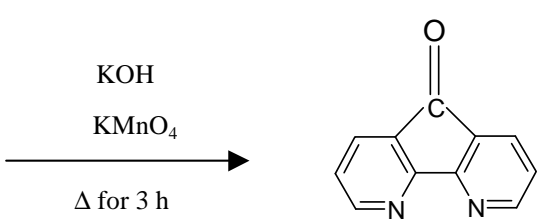

4,5 diazafluoren-9-one (dafone)
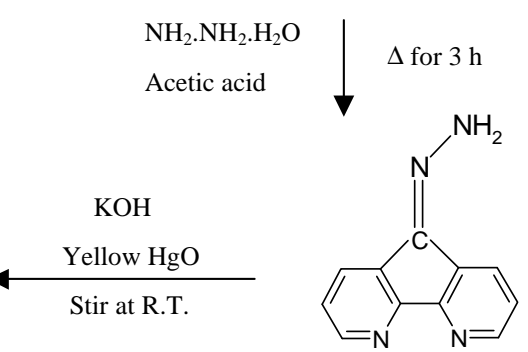

4,5 diazafluorenone 9-hydrazone (dzdfh)
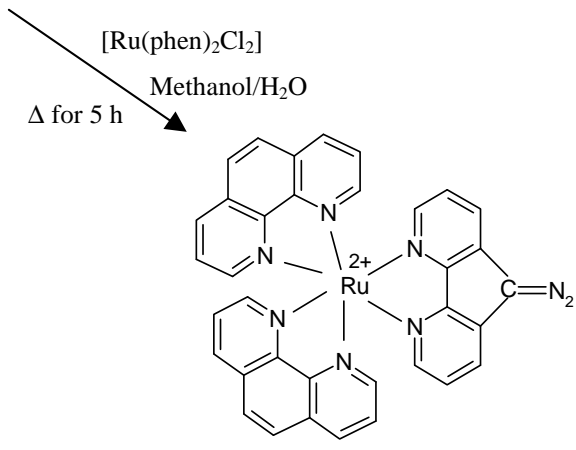

$\left[\mathrm{Ru}(\mathrm{phen})_{2} \mathrm{dzdf}\right] \mathrm{Cl}_{2}$

Figure 1. Scheme leading to synthesis of various polypyridyl ligands and $R u(I I)$ polypyridyl complexes.

(Analysis - Found: C, 49.30; H, 4.27; N, 14.58\%. Calcd. for $\mathrm{C}_{31} \mathrm{H}_{30} \mathrm{~N}_{8} \mathrm{O}_{4} \mathrm{Cl}_{2} \mathrm{Ru}$ : C, 49.59; $\mathrm{H}, 4.03 ; \mathrm{N}$, $14.93 \%$.)

$2.3 \mathrm{~b} \quad\left[R u(\text { phen })_{2}(d z d f)\right] C l_{2}:$ A mixture containing $\left[\mathrm{Ru}(\text { phen })_{2} \mathrm{Cl}_{2}\right] \quad(0.100 \mathrm{~g}, \quad 0.16 \mathrm{mmol})$ and $\mathrm{dzdf}$ $(0.032 \mathrm{~g}, 0.16 \mathrm{mmol})$ was refluxed in methanol/ water $(1: 1)$ for $5 \mathrm{~h}$ to give a dark red solution. The solution was cooled to room temperature. After evaporation of the solvent, solid was collected, washed with small amounts of methanol and diethyl ether and dried under suction. The product was purified by column chromatography on alumina using acetone and methanol as eluent. Yield $=60 \%$.

(Analysis - Found: C, 51.90; H, 3.50; N, 14.01\%. Calcd. for $\mathrm{C}_{35} \mathrm{H}_{30} \mathrm{~N}_{8} \mathrm{O}_{4} \mathrm{Cl}_{2} \mathrm{Ru}$ : C, 52.62; H, 3.78; N, $14.03 \%$.)

\subsection{Physical methods}

Microanalyses $(\mathrm{C}, \mathrm{H}$ and $\mathrm{N})$ were carried out on a Perkin-Elmer 240 Q elemental analyser at the Na- tional Chemical Laboratory, Pune. UV-Vis spectra were recorded on a Shimadzu UV-1601 spectrophotometer. ${ }^{1} \mathrm{H}$ NMR spectra were measured on a VarianMercury $300 \mathrm{MHz}$ spectrometer at room temperature and all chemical shifts are given relative to TMS. The infrared spectra were recorded on a Shimadzu FTIR-8400 spectrophotometer. Spectra of solid samples were recorded by dispersing the samples in $\mathrm{KBr}$ pellets. Steady-state emission titrations were carried out on a Shimadzu RF-5301 spectrofluorometer at room temperature.

\subsection{DNA binding experiments}

2.5a Absorption titration: Absorption titrations of $\mathrm{Ru}$ (II) complexes in buffer (phosphate, $\mathrm{pH}$ 7.2) were done using a fixed ruthenium concentration to which increments of the DNA stock solution were added. Ruthenium solutions employed were $0.020 \mathrm{mM}$ in concentration and calf thymus DNA was added to a ratio of $0-30$ [DNA]/[Ru]. Ruthenium-DNA solutions 
Table 1. IR and ${ }^{1} \mathrm{H}$ NMR spectral data.

\begin{tabular}{llllll}
\hline & \multicolumn{4}{c}{$\mathrm{IR}\left(\mathrm{cm}^{-1}\right)^{\mathrm{c}}$} & \\
\cline { 2 - 5 } Compound & $\mathrm{C}=\mathrm{C}$ & $\mathrm{C}=\mathrm{N}$ & $\mathrm{C}=\mathrm{O}$ & $\mathrm{N}=\mathrm{N}$ & \multicolumn{1}{c}{${ }^{1} \mathrm{H} \mathrm{NMR}(\delta, \mathrm{ppm})$} \\
\hline dafone $^{\mathrm{a}}$ & 1403 & 1593 & 1718 & & $8 \cdot 81(d, 2 \mathrm{H}), 8 \cdot 01(d, 2 \mathrm{H}), 7 \cdot 37(d d, 2 \mathrm{H})$ \\
dzdfh $^{\mathrm{a}}$ & 1402 & 1562 & - & & $8 \cdot 56(d d, 2 \mathrm{H}), 8 \cdot 29(d d, 2 \mathrm{H}), 7 \cdot 98(d d, 2 \mathrm{H}), 5 \cdot 37\left(\mathrm{NH}_{2}, s\right)$ \\
dzdf $^{\mathrm{a}}$ & 1410 & 1593 & - & 2060 & $8 \cdot 72(d d, 2 \mathrm{H}), 7 \cdot 91(d d, 2 \mathrm{H}), 7 \cdot 39(d d, 2 \mathrm{H})$ \\
{$\left[\mathrm{Ru}(\mathrm{bpy})_{2}(\mathrm{dzdf})\right] \mathrm{Cl}_{2}{ }^{\mathrm{b}}$} & 1421 & 1602 & - & 2104 & $8 \cdot 47(m, 5 \mathrm{H}), 8 \cdot 05(m, 9 \mathrm{H}), 7 \cdot 73(d d, 2 \mathrm{H}), 7 \cdot 46(m, 6 \mathrm{H})$ \\
{$\left[\mathrm{Ru}(\mathrm{phen})_{2}(\mathrm{dzdf}) \mathrm{Cl}_{2}{ }^{\mathrm{b}}\right.$} & 1421 & 1633 & - & 2088 & $8 \cdot 42(m, 6 \mathrm{H}), 8 \cdot 07(m, 8 \mathrm{H}), 7 \cdot 55(m, 6 \mathrm{H}), 7 \cdot 27(d, 1 \mathrm{H}), 7 \cdot 17(d, 1 \mathrm{H})$ \\
\hline
\end{tabular}

${ }^{1} \mathrm{H}$ NMR spectra were recorded in ${ }^{\mathrm{a}} \mathrm{CDCl}_{3} ;{ }^{\mathrm{b}} \mathrm{D}_{2} \mathrm{O}$; ${ }^{\mathrm{c}} \mathrm{IR}$ spectra were measured as $\mathrm{KBr}$ pellets

were allowed to incubate for $10 \mathrm{~min}$ before the absorption spectra were recorded. The intrinsic binding constant of the complex with CT-DNA was determined from the equation,

$$
\begin{aligned}
{[\mathrm{DNA}] /\left[\varepsilon_{a}-\varepsilon_{f}\right]=} & {[\mathrm{DNA}] /\left[\varepsilon_{b}-\varepsilon_{f}\right] } \\
& +1 / K_{b}\left[\varepsilon_{b}-\varepsilon_{f}\right] .
\end{aligned}
$$

through a plot of $[\mathrm{DNA}] /\left[\varepsilon_{a}-\varepsilon_{f}\right]$ versus [DNA], where [DNA] is the concentration of DNA in the base pairs. The apparent absorption coefficients $\varepsilon_{a}, \varepsilon_{f}$ and $\varepsilon_{b}$ correspond to $A_{\text {obsd }} /[\mathrm{Ru}]$, the extinction coefficient for the free ruthenium complex and the extinction coefficient for the ruthenium complex in the fully bound form respectively. The slope and $Y$ intercept of the linear fit of $[\mathrm{DNA}] /\left[\varepsilon_{a}-\varepsilon_{f}\right]$ versus [DNA] give $1 /\left[\varepsilon_{a}-\varepsilon_{f}\right]$ and $1 / K_{b}\left[\varepsilon_{b}-\varepsilon_{f}\right]$ respectively. The intrinsic binding constant $K_{b}$ can be obtained from the ratio of the slope to the $Y$-intercept. ${ }^{29}$

$2.5 \mathrm{~b}$ Luminescence titration in the presence of ethidium bromide (EB): Luminescence titration quenching experiments were conducted by adding small aliquots of $0-60 \mu \mathrm{M}$ solutions of the $\mathrm{Ru}(\mathrm{II})$ complexes to samples containing $20 \mu \mathrm{M}$ EB and $20 \mu \mathrm{M}$ DNA in buffer. The resulting solution was allowed to equilibrate for 5-10 $\mathrm{min}$ at room temperature. The Stern-Volmer quenching constant was calculated according to the classical Stern-Volmer equation, ${ }^{34}$

$$
I_{0} / I=1+K r
$$

where $I_{0}$ and $I$ are the fluorescence intensities in the absence and presence of complex respectively. $K$ is a linear Stern-Volmer quenching constant and $r$ is the ratio of the total concentration of complex to that of DNA. 2.5c Viscosity measurements: Viscosity experiments were carried out using a semi-micro viscometer maintained at $28^{\circ} \mathrm{C}$ in a thermostatic water bath. Flow time was recorded three times for each sample and average flow time was calculated. Data were presented as $\left(\eta / \eta^{\circ}\right)^{1 / 3}$ versus binding ratio, where $\eta$ is the viscosity of DNA in the presence of complex and $\eta^{\circ}$ is the viscosity of DNA alone. ${ }^{30}$

\section{Results and discussion}

\subsection{Spectral characterization}

All the compounds synthesized in this study have been characterized by elemental analysis, UV-Vis, IR and ${ }^{1} \mathrm{H}$ NMR spectroscopic methods. Electronic absorption spectra of the complexes are characterized by metal-to-ligand charge transfer (MLCT) transitions in the visible region. The low energy bands at $446 \mathrm{~nm}, 443 \mathrm{~nm}$ for compounds [Ru(bpy $\left.)_{2}(\mathrm{dzdf})\right] \mathrm{Cl}_{2}$ and $\left[\mathrm{Ru}(\mathrm{phen})_{2}(\mathrm{dzdf})\right] \mathrm{Cl}_{2}$ respectively are assigned to the metal-to-ligand charge transfer transition. No luminescence was observed for the complexes $\left[\mathrm{Ru}(\mathrm{bpy})_{2}(\mathrm{dzdf})\right] \mathrm{Cl}_{2}$ and $\left[\mathrm{Ru}(\text { phen })_{2}(\mathrm{dzdf})\right] \mathrm{Cl}_{2}$ upon excitation in the MLCT bands either in aqueous solution or in the presence of CT DNA.The important stretching frequencies observed in the infrared spectra are listed in table $1 .{ }^{1} \mathrm{H}$ NMR spectral data for the ligands and compounds synthesized in this study are summarized in table 1 which shows the expected peaks in the aromatic region.

\subsection{DNA binding}

DNA binding of $\mathrm{Ru}(\mathrm{II})$ complexes synthesized in this study with CT DNA has been monitored by absorption titration, luminescence quenching of ethidium bromide (EB) bound to DNA by the metal complexes and viscosity measurements. 


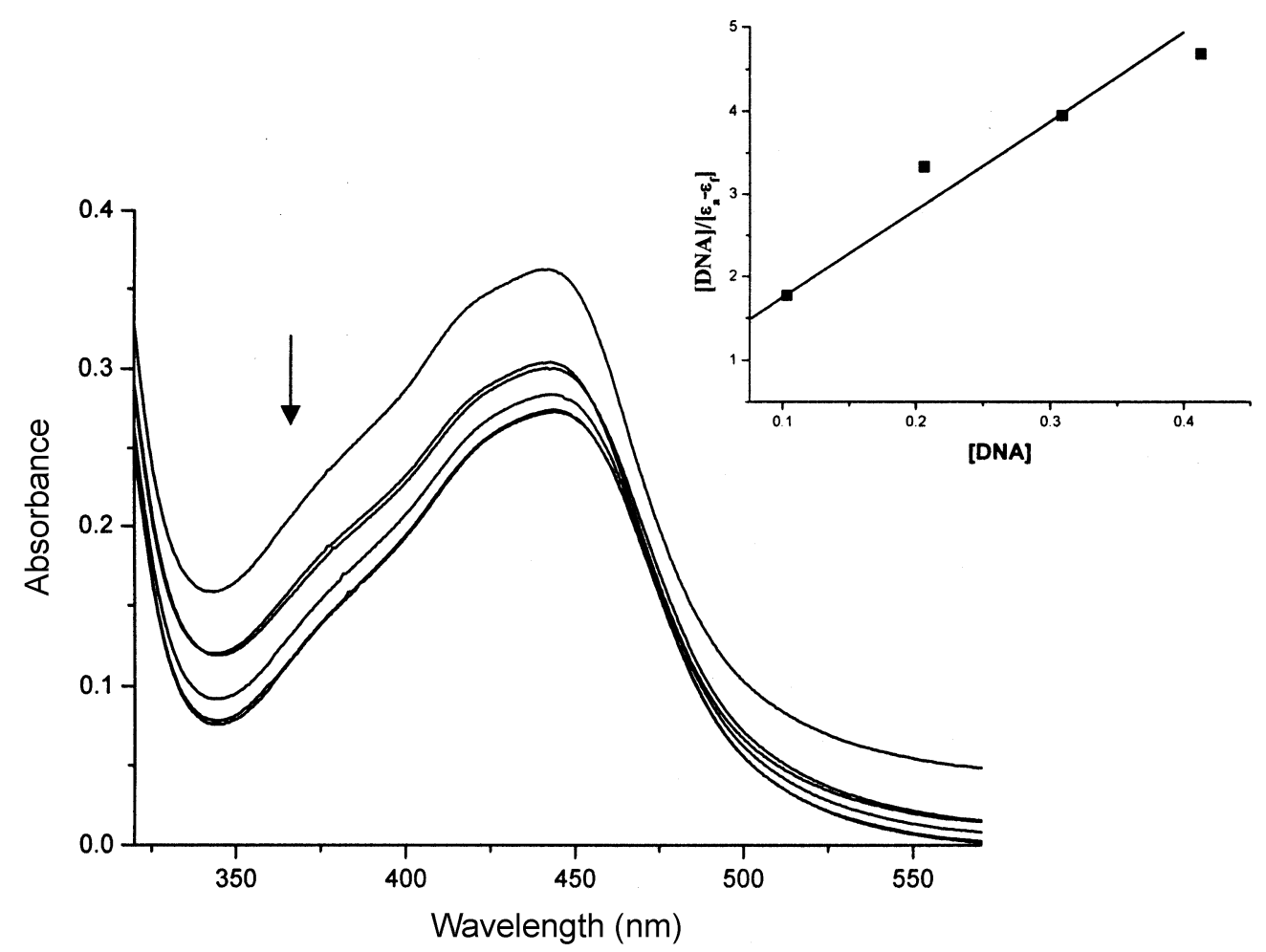

Figure 2. Absorption spectra of $\left[\mathrm{Ru}(\mathrm{phen})_{2} \mathrm{dzdf}\right] \mathrm{Cl}_{2}$ in the presence of increasing amounts of CT DNA. $[\mathrm{Ru}]=0 \cdot 020 \mathrm{mM}$, $[\mathrm{DNA}] /[\mathrm{Ru}]=0-30$. Inset illustrates the best fit of the binding data to (1) (see text for details).

Table 2. Spectroscopic properties on binding to CT DNA.

\begin{tabular}{|c|c|c|c|c|}
\hline \multirow[b]{2}{*}{ Compound } & \multicolumn{2}{|c|}{ Absorption $^{\mathrm{a}}$} & \multirow[b]{2}{*}{$\lambda_{\max }(\mathrm{nm}) \Delta \lambda$} & \multirow[b]{2}{*}{$K_{b}$} \\
\hline & Free $\left(\varepsilon \mathrm{M}^{-1} \mathrm{~cm}^{-1}\right)$ & Bound $^{\text {b }}$ & & \\
\hline$\left[\mathrm{Ru}(\mathrm{bpy})_{2}(\mathrm{dzdf})\right] \mathrm{Cl}_{2}$ & $446\left(1.73 \times 10^{3}\right)$ & 447 & 1 & - \\
\hline$\left[\mathrm{Ru}(\text { phen })_{2}(\mathrm{dzdf})\right] C l_{2}$ & $440\left(2.97 \times 10^{3}\right)$ & 443 & 3 & $6.83 \times 10^{3}$ \\
\hline$\left[\mathrm{Ru}(\mathrm{bpy})_{3}\right] \mathrm{Cl}_{2}$ & 452 & 452 & 0 & - \\
\hline$\left[\mathrm{Ru}(\mathrm{phen})_{2}(\mathrm{dppz})\right] \mathrm{Cl}_{2}{ }^{\mathrm{c}}$ & 437 & 440 & 3 & $>10^{6}$ \\
\hline
\end{tabular}

${ }^{\mathrm{a}}[\mathrm{Ru}]=0.020 \mathrm{mM}$; all solutions in phosphate buffer $(7 \cdot 2) ;{ }^{\mathrm{b}}[\mathrm{DNA}] /[\mathrm{Ru}]=30$; ${ }^{\mathrm{c}}$ data from ref. [22a]

3.2a Absorption titration: Absorption titration can be used to observe the interaction of the complex with DNA. In general, hypochromism and red-shift are associated with the binding of the complex to the helix by an intercalative mode involving strong stacking interaction of the aromatic chromophore of the complexes between the DNA base pairs. ${ }^{31}$ The absorption spectra of complex $\left[\mathrm{Ru}(\text { phen })_{2}(\mathrm{dzdf})\right] \mathrm{Cl}_{2}$ in the absence and presence of CT DNA is given in figure 2 and the data tabulated in table 2. Only very weak hypochromism and spectral shift were found after complex $\left[\mathrm{Ru}(\mathrm{bpy})_{2}(\mathrm{dzdf})\right] \mathrm{Cl}_{2}$ was mixed with
CT DNA. These optical changes are unlike those observed for proven intercalators (e.g. $\left[\mathrm{Ru}(\mathrm{phen})_{2}\right.$ $\left.\mathrm{dppz}]^{2+}\right)$, but very similar to that of $\left[\mathrm{Ru}(\mathrm{bpy})_{3}\right]^{2+} \cdot 13,32$ However, for complex $\left[\mathrm{Ru}(\mathrm{phen})_{2}(\mathrm{dzdf})\right] \mathrm{Cl}_{2}$, hypochromism and red shift are observed and binding constant estimated using (1) is of the order of $10^{3}$ (see figure 2 inset).

$3.2 \mathrm{~b}$ Luminescence titration in the presence of ethidium bromide $(E B)$ : No luminescence was observed for the complexes $\left[\mathrm{Ru}(\mathrm{bpy})_{2}(\mathrm{dzdf})\right] \mathrm{Cl}_{2}$ and $\left[\mathrm{Ru}(\mathrm{phen})_{2}(\mathrm{dzdf})\right] \mathrm{Cl}_{2}$ upon excitation at the MLCT 
bands either in aqueous solution or in the presence of CT DNA. Hence, competitive binding studies using ethidium bromide (EB) bound to DNA was carried out for these complexes. The quenching extent of fluorescence of EB bound to DNA is used to determine the binding of the complex and DNA. Binding of the complex results in the displacement of bound EB molecule with a reduction of emission intensity due to fluorescence quenching of free EB by water. The addition of the complex $\left[\mathrm{Ru}(\text { phen })_{2}(\mathrm{dzdf})\right] \mathrm{Cl}_{2}$ to

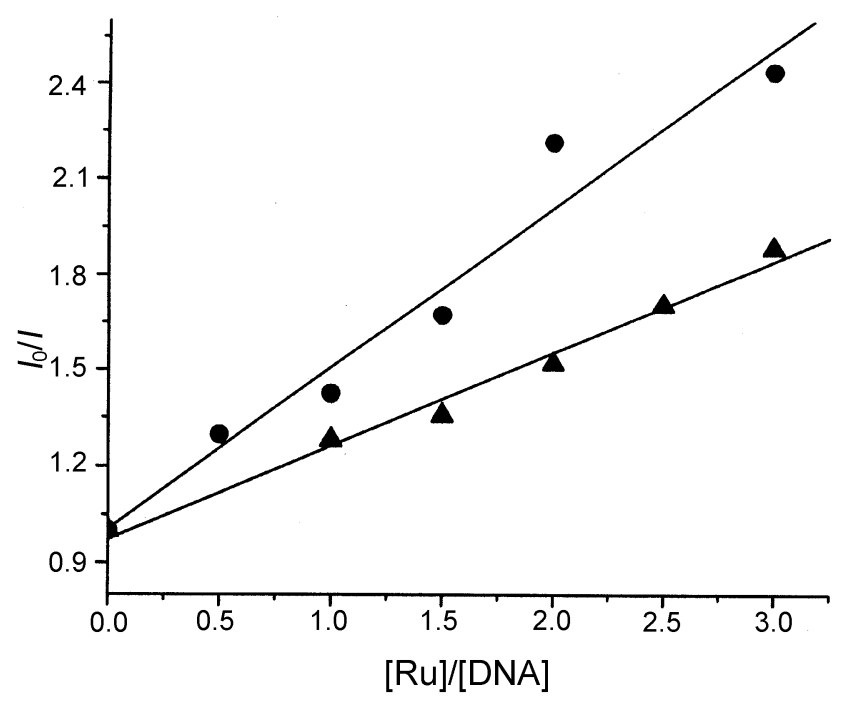

Figure 3. Fluorescence quenching curves of ethidium bromide bound to DNA in the presence of $(\boldsymbol{\Delta})\left[\mathrm{Ru}(\mathrm{bpy})_{2}\right.$ dzdf $] \mathrm{Cl}_{2}$ and $(\bullet)\left[\mathrm{Ru}(\text { phen })_{2} \mathrm{dzdf}\right] \mathrm{Cl}_{2} \quad([\mathrm{~EB}]=20 \mu \mathrm{M}$, $[\mathrm{DNA}]=20 \mu \mathrm{M},[\mathrm{Ru}]=0-60 \mu \mathrm{M})$.

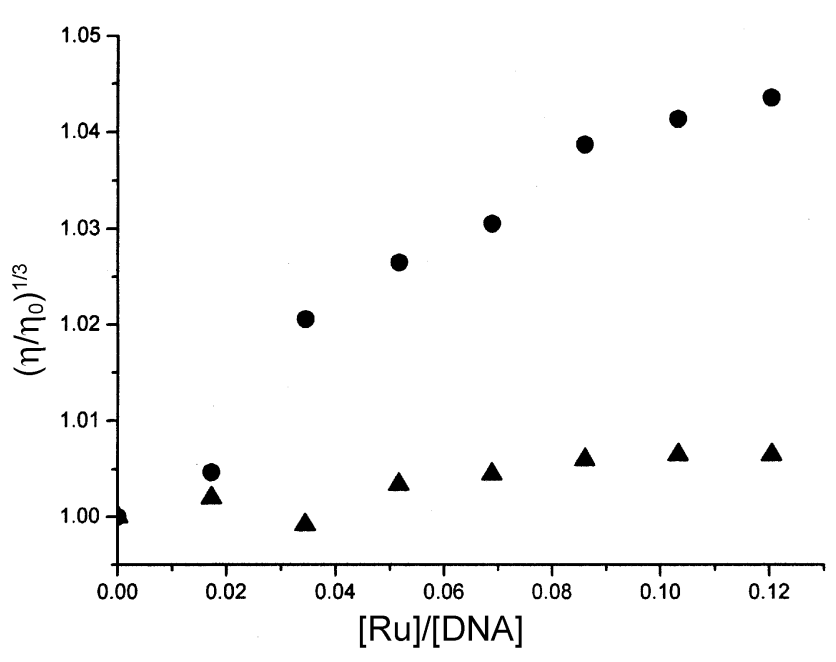

Figure 4. Effect of increasing amounts of $(\boldsymbol{\Delta})\left[\mathrm{Ru}(\mathrm{bpy})_{2}\right.$ $(\mathrm{dzdf})] \mathrm{Cl}_{2}$ and $(\bullet)\left[\mathrm{Ru}(\text { phen })_{2}(\mathrm{dzdf})\right] \mathrm{Cl}_{2}$ on the relative specific viscosity of CT DNA. ([DNA] $=0.2 \mathrm{mM}$, [Ru]/ $[\mathrm{DNA}]=0-0 \cdot 12)$.
DNA pretreated with EB causes appreciable reduction in the emission intensity, indicating that the displacement of the EB fluorophore by the complex $\left[\mathrm{Ru}(\text { phen })_{2}(\mathrm{dzdf})\right] \mathrm{Cl}_{2}$ results in a decrease of the binding of the ethidium to the DNA. However, very small decrease in emission intensity is observed for the complex $\left[\mathrm{Ru}(\mathrm{bpy})_{2}(\mathrm{dzdf})\right] \mathrm{Cl}_{2}$ indicating very weak binding affinity of this complex with CT DNA.

The fluorescence quenching curves of EB bound to DNA by the $\mathrm{Ru}$ (II) complexes are shown in figure 3 . In the plot of $I_{0} / I$ versus $[\mathrm{Ru}] /[\mathrm{DNA}], K$ is given by the ratio of the slope to the intercept. The $K$ values for $\left[\mathrm{Ru}(\mathrm{bpy})_{2}(\mathrm{dzdf})\right] \mathrm{Cl}_{2}$ and $\left[\mathrm{Ru}(\mathrm{phen})_{2}(\mathrm{dzdf})\right] \mathrm{Cl}_{2}$ estimated using (2) are 0.28 and 0.50 respectively, and suggest that the interaction of the complex $\left[\mathrm{Ru}(\text { phen })_{2}(\mathrm{dzdf})\right] \mathrm{Cl}_{2}$ with DNA is strong as compared to that with $\left[\mathrm{Ru}(\mathrm{bpy})_{2}(\mathrm{dzdf})\right] \mathrm{Cl}_{2}$ which is consistent with the above absorption spectral results.

3.2c Viscosity measurements: Viscosity measurements were carried out, which are sensitive to change in length and are regarded as the most critical tests for the binding mode of complexes with DNA. The effect of the complexes $\left[\mathrm{Ru}(\mathrm{bpy})_{2}(\mathrm{dzdf})\right] \mathrm{Cl}_{2}$ and $\left[\mathrm{Ru}(\mathrm{phen})_{2}(\mathrm{dzdf})\right] \mathrm{Cl}_{2}$ on the viscosity of CT DNA is shown in figure 4 . Two different kinds of behaviour can be distinguished by this experiment. Complex $\left[\mathrm{Ru}(\mathrm{bpy})_{2}(\mathrm{dzdf})\right] \mathrm{Cl}_{2}$ which exhibits a decrease in viscosity with increase in metal complex concentration indicates an electrostatic association of this complex with CT DNA. For complex $\left[\mathrm{Ru}(\mathrm{phen})_{2}(\mathrm{dzdf})\right] \mathrm{Cl}_{2}$, the viscosity of DNA increases with the increase of the concentration of the complex indicating intercalative binding mode.

\section{Conclusions}

Weak hypochromism and spectral shift and decrease in viscosity with increasing metal complex concentration indicate that the complex $\left[\mathrm{Ru}(\mathrm{bpy})_{2}(\mathrm{dzdf})\right] \mathrm{Cl}_{2}$ may bind to DNA by an electrostatic binding mode. Pronounced hypochromism and red-shift, and increase in viscosity with increasing metal complex concentration observed for the complex [Ru(phen $\left.)_{2}(\mathrm{dzdf})\right]$ $\mathrm{Cl}_{2}$ indicates an intercalative binding mode. SternVolmer quenching constants for $\left[\mathrm{Ru}(\mathrm{bpy})_{2}(\mathrm{dzdf})\right] \mathrm{Cl}_{2}$ and $\left[\mathrm{Ru}(\mathrm{phen})_{2}(\mathrm{dzdf})\right] \mathrm{Cl}_{2}$ are 0.28 and 0.50 respectively, suggesting that the interaction of the complex $\left[\mathrm{Ru}(\text { phen })_{2}(\mathrm{dzdf})\right] \mathrm{Cl}_{2}$ with CT DNA is the strongest, which is consistent with the above absorption spectral results and viscosity measurements. 


\section{Acknowledgements}

ASK acknowledges the financial assistance from the Council of Scientific and Industrial Research, New Delhi. MSD thanks the Bhabha Atomic Research Centre, Mumbai, India for a research fellowship.

\section{References}

1. (a) Tullius T D 1989 In Metal-DNA chemistry (ed.) T D Tullius, ACS Symp. Ser. No. 402 (Washington, DC: Am. Chem. Soc.) pp 1-23; (b) Kelly S O and Barton J K 1999 In Metal ions in biological systems (eds) A Sigel and H Sigel (New York: Marcel Dekker) 39211

2. Erkkila K E, Odom D T and Barton J K 1999 Chem. Rev. 992777

3. Sigman D S, Mazumder A and Perrin D M 1993 Chem. Rev. 932295

4. Eriksson M, Leijon M, Hiort C, Norden B and Graslund A 1994 Biochemistry 335031

5. Hudson B P, Dupureur C M and Barton J K 1995 J. Am. Chem. Soc. 1179379

6. Terbrueggen R H and Barton J K 1995 Biochemistry 348227

7. Lecomte J P, Kirsch-De Mesmaeker A and Kelly J M 1996 Top. Curr. Chem. 17725

8. Lincoln P and Norden B 1998 J. Phys. Chem. B102 9583

9. Barton J K 1986 Science 233727

10. Barton J K, Dannenberg J J and Raphael A L 1982 J. Am. Chem. Soc. 1044967

11. Barton J K, Danishefsky A T and Goldberg J M 1984 J. Am. Chem. Soc. 1062172

12. Barton J K and Raphael A L 1985 Proc. Acad. Sci. USA 826460

13. Kumar C V, Barton J K and Turro N J 1985 J. Am. Chem. Soc. 1075518

14. (a) Jackson B A and Barton J K 1997 J. Am. Chem. Soc. 119 12986; (b) Jackson B A, Alekseyev V Y and Barton J K 1999 Biochemistry 38 4655; (c) Jackson B A and Barton J K 2000 Biochemistry 396176.

15. (a) Feeney M M, Kelly J M, Tossi A, Kirsch-De Mesmaeker A and Lecomte J P 1994 J. Photochem. Photobiol. B23 69; (b) Kelly J M, Feeney M M, Tossi A, Lecomte J P and Kirsch-De Mesmaeker A 1990 AntiCancer Drug Design 5 69; (c) Jacquet L, Davies R J H, Kirsch-De Mesmaeker A and Kelly J M 1997 J. Am. Chem. Soc. 11911763

16. (a) Friedman A E, Chambron J C, Sauvage J P, Turro N J and Barton J K $1990 \mathrm{~J}$. Am. Chem. Soc. 112 4960; (b) Hartshorn R M and Barton J K 1992 J. Am. Chem. Soc. 114 5919; (c) Jenkins T, Friedman A E, Turro N and Barton J K 1992 Biochemistry 31 10809; (d) Coates C G, Jacquet L, McGarvey J J, Bell S E J, Obaidi A H R and Kelly J M 1997 J. Am. Chem. Soc.
119 7130; (e) Tuite E, Lincoln P and Norden B 1997 J. Am. Chem. Soc. 119 239; (f) Haq I, Lincoln P, Suh D, Norden B, Chowdhry B Z and Chaires J B 1995 J. Am. Chem. Soc. 1174788

17. (a) De Buyl F, Kirsch-De Mesmaeker A, Tossi A and Kelly J M 1991 J. Photochem. Photobiol. A60 27; (b) Lecomte J P, Kirsch-De Mesmaeker A, Feeney M M and Kelly J M 1995 Inorg. Chem. 346481

18. Moucheron C, Kirsch-De Mesmaeker A and Choua S 1997 Inorg. Chem. 36584.

19. Collins J G, Sleeman A D, Aldrich-Wright J R, Greguric L and Hambley T W 1998 Inorg. Chem. 373133

20. (a) Turro C, Bossmann S H, Jenkins Y, Barton J K and Turro N J 1995 J. Am. Chem. Soc. 117 9026; (b) Hiort C, Lincoln P and Norden B 1993 J. Am. Chem. Soc. 1153448.

21. Ortmans I, Benjamin E, Kelly J M, Moucheron C and Kirsch-De Mesmaeker A 2004 J. Chem. Soc., Dalton Trans. 668

22. (a) Zhen O-X, Zhang O-L, Liu J-G, Ye B-H and Ji LN 2000 J. Inorg. Biochem. 78 293; (b) Liu J-G, Zang Q-L and Ji L-N 2001 Transition Met. Chem. 26 733; (c) Chao H, Mei W-J, Huang O-W and Ji L-N 2002 J. Inorg. Biochem. 92 165; (d) Yang G, Wang L and Ji L-N 1997 J. Inorg. Biochem. 67 289; (e) Yang G, Wu J-Z, Wang L, Ji L-N and Tian X 1997 J. Inorg. Biochem. 66 141; (f) Wu J-Z, Li L, Tian X, Ji L-N, Zhou J-Y and Li R-H 1997 Polyhedron 16103.

23. (a) Arounaguiri S and Maiya B G 1999 Inorg. Chem. 38 842; (b) Ambroise A and Maiya B G 2000 Inorg. Chem. 39 4256; (c) Ambroise A and Maiya B G 2000 Inorg. Chem. 39 4264; (d) Kulkarni M S, Rao B S M, Sastri C V, Maiya B G, Mohan H and Mittal J P 2004 J. Photochem. Photobiol. A167 101; (e) Murali S, Sastri C V and Maiya B G 2002 Proc. Indian Acad. Sci. (Chem. Sci.) $\mathbf{1 1 4} 403$

24. Eppley H J, Lato S M, Ellington A D and Zaleski J M 1999 Chem. Commun. 2405

25. Marmur J 1961 J. Mol. Biol. 3208

26. Henderson L J, Fronczek F R and Cherry W R 1984 J. Am. Chem. Soc. 1065876

27. Kraft B J, Eppley H J, Huffman J C and Zaleski J M 2002 J. Am. Chem. Soc. 124272

28. Sullivan B P, Salmon D and Meyer T J 1978 Inorg. Chem. 173334

29. Wolfe A, Shimer G H and Meehan T 1987 Biochemistry 266392

30. Cohen G and Eisenberg H 1969 Biopolymers 845

31. Norden B, Lincoln P, Akerman B and Tuite E 1996 In Metal ions in biological systems (eds) A Sigel and H Sigel (New York: Marcel Dekker) 33177

32. Friedman A E, Kumar C V, Turro N J and Barton J K 1991 Nucleic Acids Res. 192595

33. Baguley B C and LeBret M 1984 Biochemistry 23 937

34. Lakowicz J R and Webber G 1973 Biochemistry 12 4161 